\title{
浸透水圧を受ける砂のせん断強度について* \\ ON THE STUDY OF SHEAR STRENGTH OF SAND UNDER SEEPAGE PRESSURE
}

\author{
内田一郎**・村田重之*** \\ By Ichiro UCHIDA and Shigeyuki MURATA
}

\section{1. まえがき}

土の問題は土と水との関係の問題であるといわれるほ ぞ土中の水の存在は重要な問題であるが, 土中の水はそ れが静止しているか流動しているかによって取り扱いが 違ってくる.つまり地盤内の水が静止状態にある場合に は土粒子に作用するのは間隚水圧のみであるが，流動状 態にある場合には地盤の骨格を構成する土粒子には水と 粒子壁面間で粘性抵抗が働くため，土粒子は流線の方向 に力を受けることになる.この力は浸透水圧とよばれ， 水が間隚を流れることによって失われるエネルギーであ る.この浸透水圧はパイピングやボイリングあるいはヒ 一ビングなどを引き起こすことでよく知られているが, これらの現象がさらに進行すればアースダムやロックフ イルダム，河川堤防など遮水を目的とする盛土構造物の 破壞, あるいは建物の基礎や地中構造物施工時の根切り 底面の不安定などにつながる．特に近年の土木工事の機 械化・大型化はその危険性をますます増大させてきてい る. すなわち水資源開発の進展に伴い次第に良好なダム サイトが少なくなり，厚い砂砶基盤上にもアースダムや ロックフィルダムを筑造する必要性が増大し2)，また， 河川流域の大規模な開発と都市化は降雨時の河川流量を 急激に増大させ，さらに市街地における建築物の大型 化・高層化，地下街や地下鉄の建設などによる $-30 \mathrm{~m}$ を超えるような大規模な掘削などがその典型的な例であ $\sigma^{3)}$.

ところで，これらの破壊現象は，破壊が連鎖反応的に 進さいわ汸る進行性破壊の1つとみなされるが，破壊に 至る過程においては浸透水圧の作用による土の強度低下

* 本研究の一部は, 参考文献 1)で発表したが, この論文汶 その後の研究成果を加えて取りまとめたものである.

** 正会員 工博 九州大学教授 工学部土木工学科

*** 正会員 九州大学助手 工学部土木工学科
が重要な問題となってくると思われる．パイピングやボ イリングに関する研究はこれまでにも模型実験などによ る数多くの研究があり ${ }^{4), 5)}$ ，定性的にはかなりの成果が 納められているようである。しかしながら浸透水圧を土 粒子が流線の方向に受ける物体力としてとらえ，それが 土の強度にどのような影響を及ぼしているのかを定量的 に明らかにした例は極めて少ないようである.

本研究はこれらの点に着目し，浸透水圧を受けること によって土のせん断強度がどのように変化するのか，ま た浸透水圧と間隚水圧との間にどのような関係があるの かを明らかにし，実際の安定解析に対して基礎的な資料 を提供することを目的に行っている．本論文は，三軸圧 縮条件下の砂供試体中に浸透水を供試体の底部から上部 へ向けて流し，その状態でせん断破壊を起こさせる一連 の実験結果を取りまとめたものである。

\section{2. 試料および試験方法}

\section{（1）試料と供試体作成}

試料には豊浦砂 $\left(G_{s}=2.64, D_{10}=0.17 \mathrm{~mm}\right.$ ，均等係数 1.4）と，一般的な砂の粒径分布を示すものとして九大 砂 $\left(G_{s}=2.64, D_{10}=0.22 \mathrm{~mm}\right.$, 均等係数 3.1) の 2 種類 を使用した．図一1 にその粒径加積曲線を示す.

供試体は，内部にゴムスリーブをセットした 2 つ割り

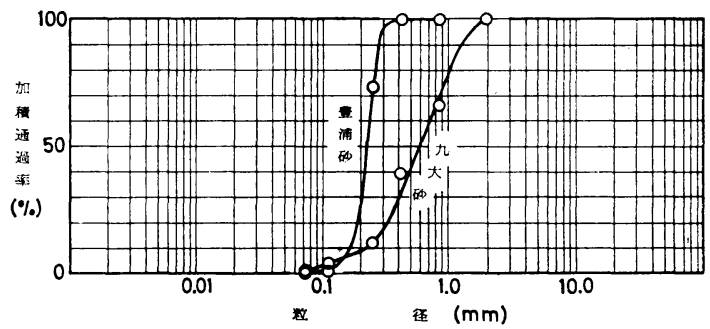

図一1＼cjkstart試料の粒径加栍曲線 
にできる砂供試体作成用モールド内に，空気乾燥した試 料を 5 層に分け各層を同一回数突き棒で締固め作成し た。供試体は直径約 $5.0 \mathrm{~cm}$, 高さ約 $12.6 \mathrm{~cm}$ の円筒型 で, 初期間隚比 $\left(e_{0}\right)$ は豊浦砂約 0.65 , 九大砂約 0.59 であった。

\section{（2）試験装置・計測および試験方法}

試験装置は一般に使用されている三軸圧縮試験機を 図一2 のように改良したもので，通常の操作および計測 は一般のそれと同様である.この改良した試験機の特徴 は浸透水の供給と間隚水圧の測定法にある.つまりコン プレッサーからの圧力は, エアーレギュレーターによっ て所定の圧力に調整され，この圧力の作用で浸透水供給 タンクの水は供試体の中を底部から上部へ向かって流れ 三軸室外一排水される構造となっている. 間嚐水圧の測 定は図一3のように供試体の軸方向に約 $2.4 \mathrm{~cm}$ 間隔 (九大砂では上中下の 3 か所) で 医学用の注射針（豊浦 砂では外径 $0.8 \mathrm{~mm}$, 九大砂では外径 $1.2 \mathrm{~mm}$ ) を差し 込み行った．注射針のゴムスリーブへの差し込み口は， 瞬間接着沜を使用して完全に密着し水漏れを防いだ．間

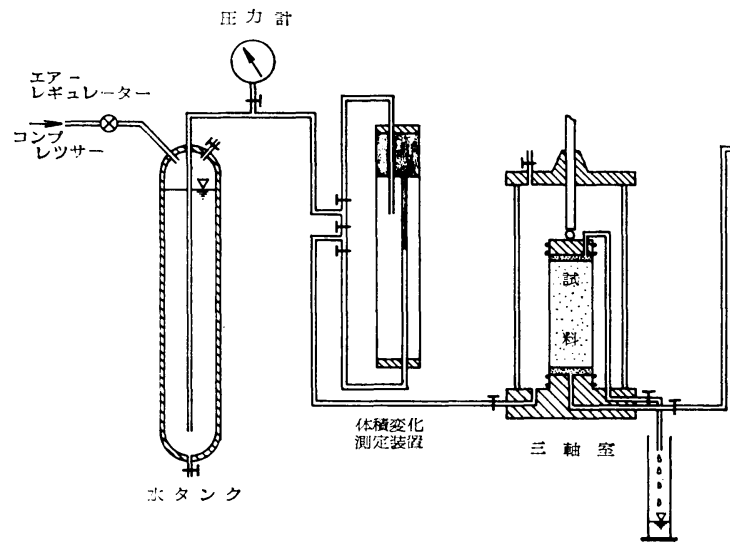

図一2 試験装置の概略図

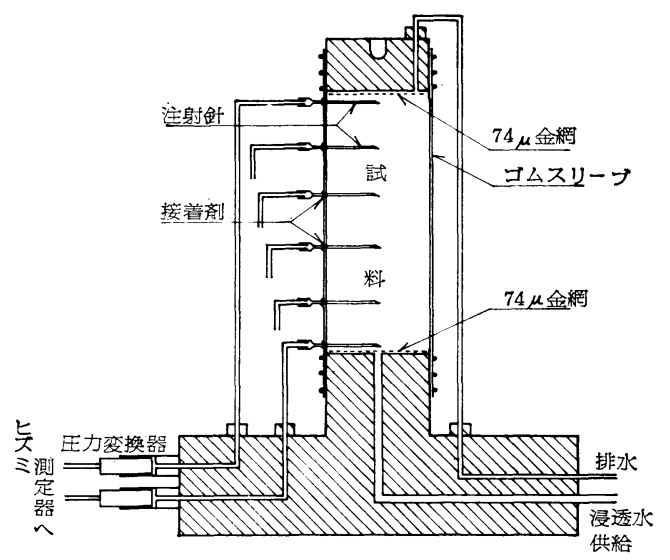

図一3 間隙水圧の計測図
隚水圧の測定には小型圧力変換器を使用した.

試験は次のような手順で行った。まず $2 つ$ 割れモール ド内に突き固めた供試体に載荷キャップを取り付け，ゴ ムスリーブを輪ゴムで固定する．次にモールドの片側だ けをはずし残りのモールドを支えにして所定の位置に注 射針を差し込み挿入口を接着剤で密着する．30６0 分 後接着剤が固まったら残りのモールドをはずし，供試体 の底部から約 $0.03 \mathrm{~kg} / \mathrm{cm}^{2}$ の圧力で水を浸透させ, 供試 体内に空気が残らないように徐々に飽和させる．同時に 注射針から圧力変換器までの管内の空気も追い出す.こ れらが完了したら浸透水の供給を中断し三軸室を組み立 てる. 三軸室に水を満たし側圧をかけたのち，供試体の 底部から所定の圧力の浸透水を送り上部からパイプを通 じて三軸室外一排水する.この状態で約 1 時間圧密した のち約 $0.7 \% / \mathrm{min}$ の軸ひずみ速度で圧縮し破壊に至ら しめる. 圧密・圧縮の両過程を通じて間隚水圧と流出水 量を, 圧縮中はさらに圧縮力と体積変化量を測定した。

本論文では上記のように浸透水を上部から排水させる タイプを「透水型」，排水をさせないタイプを「不透水 型」とよぶことにする．「不透水型」はいわゆるバック プレッシャーをかけた状態に相当
E 万 計

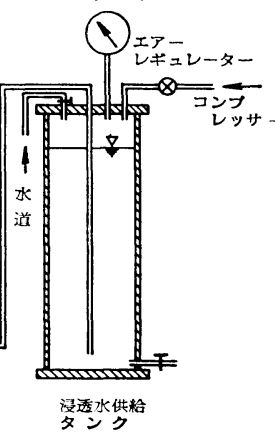

\section{（1）間隙水圧分布}

間隊水圧は供試体内に差し込ん だ注射針によって圧密・圧縮の両過程を通じて測定を行 ったが，その間，間隚水圧の值にほとんど変化はなかっ た. 図一4 (a), (b) に豊浦砂と九大砂の軸方向の間隙水 圧分布を， 5 種類の $r_{w} h / \sigma_{3}$ に対しそれぞれ 4 種類の側 圧について示す．間隚水圧は両者とも底部から上部へ向 かってほぼ直線的に減少して台形状の分布をなしてい る.しかし， $r_{w} h / \sigma_{3}$ が大きくなると底部と上部との水 圧に差が現われ，間隚水圧の分布形状にわずかずつ違い が生じている．また豊浦砂と九大砂では前者の方でその 差が大きく現われている.

さらに注射針の長さを変えて同一平面内の間隚水圧分 布も調べたが，供試体の中心部と周辺部との間に水圧の 差は認められず，したがって同一平面内での透水性のむ 


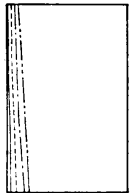

$\gamma_{w} h / \sigma_{3}=0.2$

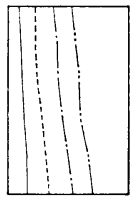

0.8

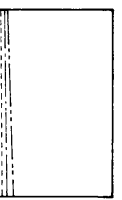

$\gamma_{w} h / \sigma_{3}=0.2$

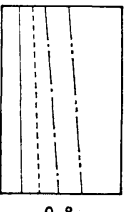

0.8

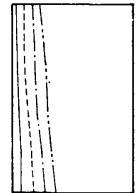

0.4

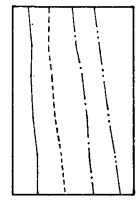

1.0

(a) 豊 浦 砂

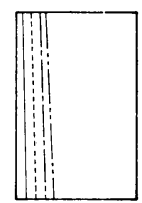

0.4

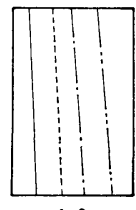

(b) 九大 砂
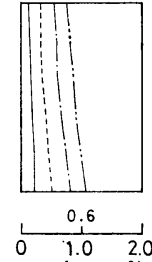

水珐 $\left(\mathrm{kg} / \mathrm{cm}^{2}\right)$

$\longrightarrow \sigma_{3}=0.5$

1.0.
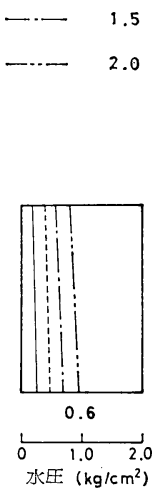

$\left[\begin{array}{c}\sigma_{3}\left(\mathrm{~kg} / \mathrm{cm}^{2}\right) \\ 0.5\end{array}\right.$

-... 1.0

- 1.5

$-\cdots, \quad 2.0$

图一4 間隙水圧分布
らや，試料とゴムスリーブとの境界での特異な流れなど はなかったといえる。

\section{（2）透 水 性}

図一5 は試験中に測定した流出水量から 計算した平均流速（v）と動水勾配（i） と の関係を示したもので，図中の○印は豊 浦砂， $\square$ 印は九大砂の結果を表わしてい る.これより本実験での両供試体内の間隚 水の流れはダルシーの法則の成立する範囲 内であったといえる.また，このグラフの 傾き，すなわち 透水係数 $(k)$ は豊浦砂よ り九大砂の方がわずかに大きくなっている が,これと同様な結果が定水位透水試験か らも得られている.したがって間隚水圧分 布のところで述べた分布形状の違いもこれ から納得される。

\section{（3）軸差応力-体積変化-軸ひずみ関係}

図一6 (a), (b) に豊浦砂, 図一7 (a), (b) に九大砂のそれぞれ透水型と不透水型の軸
差応力 $\left(\sigma_{1}-\sigma_{3}\right)$-体積変化 $(\Delta V / V)$-軸ひずみ $(\varepsilon)$ 関係を 側圧 $2.0 \mathrm{~kg} / \mathrm{cm}^{2}, r_{w} h=0,0.2,1.0,1.8 \mathrm{~kg} / \mathrm{cm}^{2}$ の場合 について示す. 図中の数字は $r_{w} h$ の值を示し, 曲線上 の矢印は破壊点を示す.これらの図において $\gamma_{w} h=0$ の 曲線は三軸圧縮試験での飽和砂の排水試験と同一のもの を表わすことになる.

まず透水型について考察すると，豊浦砂，九大砂とも 軸差応力は $r_{w} h$ の増加に従って次第に低下してくる. また破壊時の軸ひずみも $r_{w} h$ の増加に従って小さくな っている. 一方, 体積変化は豊浦砂では $\gamma_{w} h$ の増加に 従って少しずっ大きくなっているが，九大砂ではこの傾

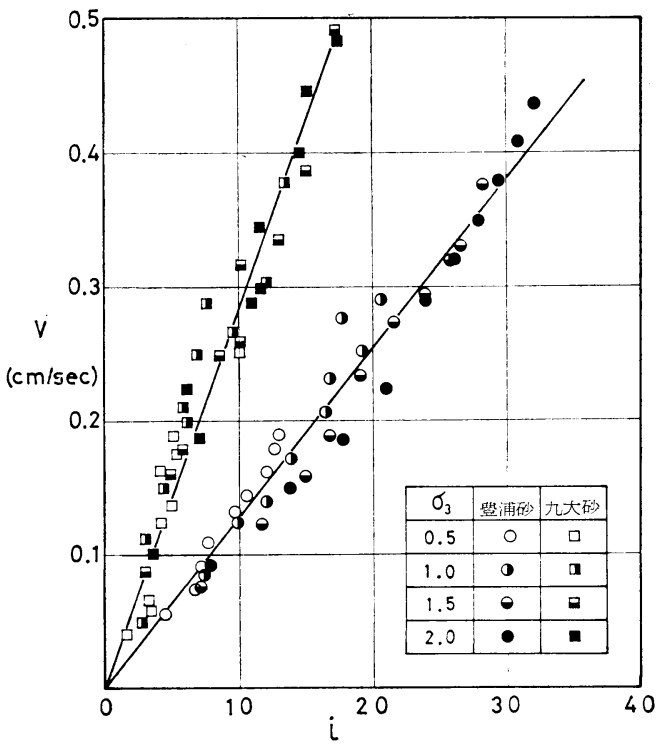

図一5 平均流速と動水勾配の関係

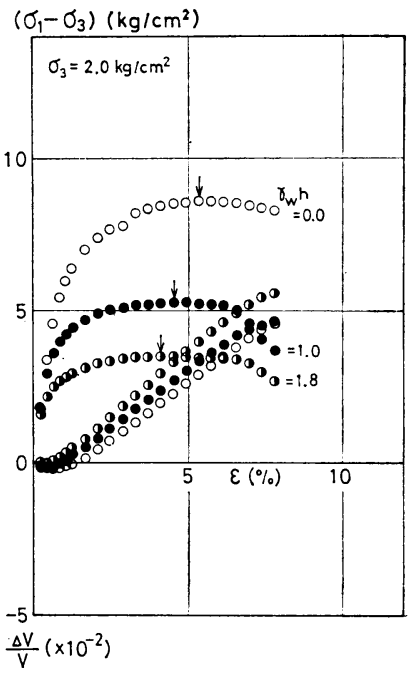

（a）透水型

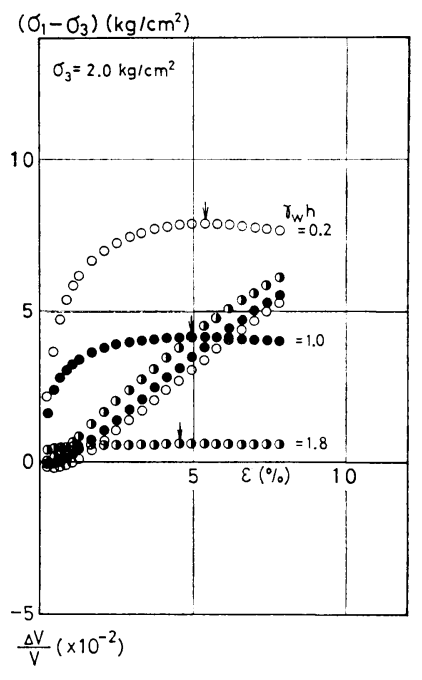

（b）不透水型

図一6 曹浦砂の軸差応力-体積变化-軸ひずみ関係 


\section{$\left(\sigma_{1}-\sigma_{3}\right)\left(\mathrm{kg} / \mathrm{cm}^{2}\right)$}

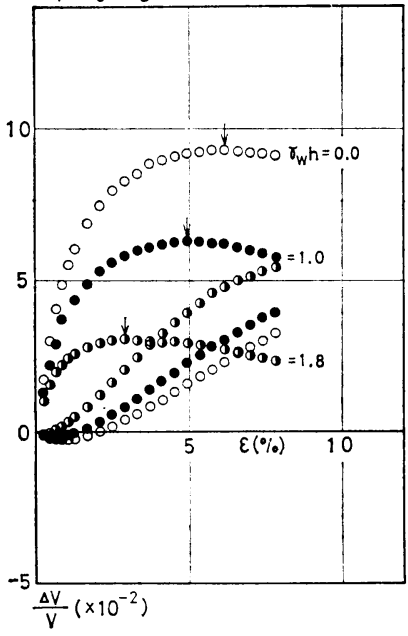

（a）透水型

図一7 九大砂の軸差応力-体積変化-軸ひずみ関係
向がよりはっきりと現われ大きな体積変化が起こってい る.

不透水型では, $r_{w} h$ は三軸圧縮試験でのバックプレッ シャーに相当するので，供試体全体にわたって $r_{w} h$ が 間隚水圧として作用することになる.したがって同一の $r_{w} h$ であってもその影響は不透水型の方に顕著に現わ れ, $r_{w} h$ の増加に対する軸差応力の低下は透水型に比べ て不透水型の方に顕著に現われることになり, その結果 が図一6，7 にもはっきりとでている.しかし破壊時の 軸ひずみや体積変化は透水型とほぼ同様な傾向を示して いる.

同一試料で透水型と不透水型を比較してみると, 両者 の間ではっきりと違いが認められるのは軸差応力につい てであり，破壊時の軸ひずみや体積変化に ははっきりとした相違は認められない。

\section{（4）軸差応力と主応力比}

破壊時の軸差応力 $\left[\left(\sigma_{1}-\sigma_{3}\right)_{f}\right] と \gamma_{w} h / \sigma_{3}$ の関倸について, 豊浦砂の透水型と不透 水型を図一8 (a)，(b) に示す. 両者とも $\tau_{w} / h / \sigma_{3}$ の増加に従って $\left(\sigma_{1}-\sigma_{3}\right)_{f}$ は直線的 に減少しているが，減少の程度は側圧によ って異なり，側圧が大きくなるほど $\left(\sigma_{1}-\right.$ $\left.\sigma_{3}\right)_{f}$ の減少が著しくなっている. 一方, 透水型と不透水型とでは前節でも明らかな ように不透水型の方が $\left(\sigma_{1}-\sigma_{3}\right)_{f}$ の減少が 著しくなっている. ちなみに $r_{w} h / \sigma_{3}=0.9$ では $\gamma_{w} h$ の作用により砂の骨格構造が破 壊されて供試体が自立しなくなる現象が観 察された.

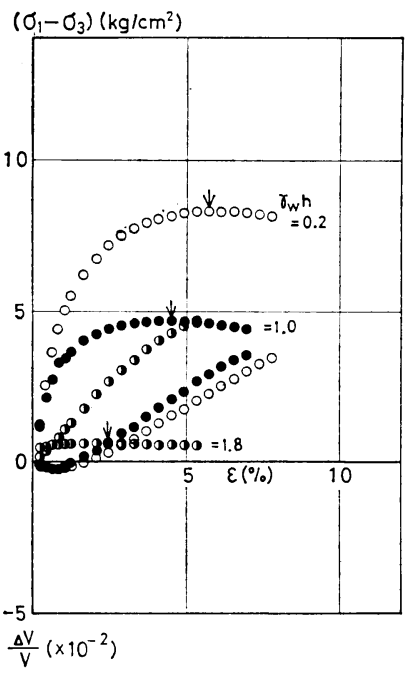

（b）不透水型
図一9 (a)，(b) はこれらの関係を破壊時 の主応力比 $\left(\sigma_{1} / \sigma_{3}\right)_{f}$ と $r_{w} h / \sigma_{3}$ の関係で 整理したもので，それぞれ透水型と不透水 型を示している.このような整理をすると 図一8に㧍けるすべての值は,

$$
\left(\sigma_{1} / \sigma_{3}\right)_{f}=A^{\prime}-\alpha\left(\gamma_{w} h / \sigma_{3}\right)
$$

ただし，

$$
\begin{aligned}
& A^{\prime}: r_{w} h / \sigma_{3}=0 \text { のときの }\left(\sigma_{1} / \sigma_{3}\right)_{f} \text { の } \\
& \quad \text { 值 } \\
& \alpha: \text { 係数 }
\end{aligned}
$$

なる 1 本の直線上にほぼ集まってくる，上 式から $\sigma_{3}$ を消去すると，

$$
\left(\sigma_{1}\right)_{f}=A-\alpha r_{w} h
$$

ただし, $A=A^{\prime} \sigma_{3}$

となり, 破壊時の最大主応力は $\gamma_{w} h$ の 1 次関数で表わされることになる.この関係 は透水・不透水型の両者についていえる が，直線の傾き（ $(\alpha)$ は不透水型の方が大きくなってい る.

図一10 は透水型の $\left(\sigma_{1}-\sigma_{3}\right)_{f}$ を間偿水の平均流速 $(v)$ との関係で整理したものである. 流速の増加に従って $\left(\sigma_{1}-\sigma_{3}\right)_{f}$ はほぼ直線的に減少している. 直線の傾きは 側圧によってわずかに異なっているがほぼ平行とみなせ る.したがって側圧の小さい場合には，間隚水の流速が わずかに大きくなっただけで $\left(\sigma_{1}-\sigma_{3}\right)_{f}$ は零に近づき強 度が失われることになる. ボイリング現象が拘束圧の小 さい地表面付近から進行してゆくこともこれから推測さ れる。

豊浦砂についての以上のような関係が九大砂の場合に もほぼ同様な結果として得られており，したがって，一

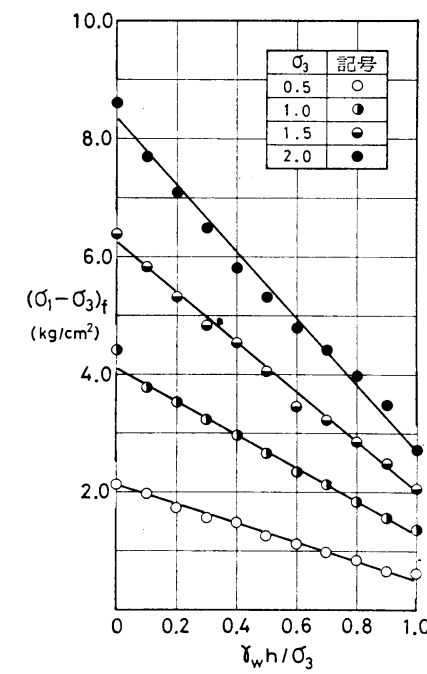

（a）透水型

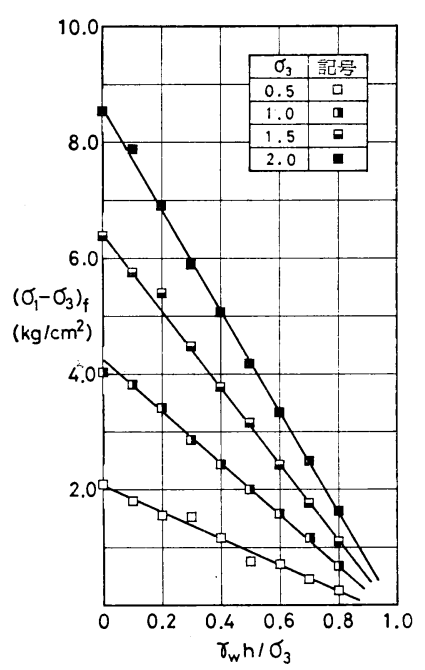

(b) 不透水型
図一8 豊浦砂の砂壊時の軸差応力と $\gamma_{w} \boldsymbol{h} / \boldsymbol{\sigma}_{8}$ の関係 


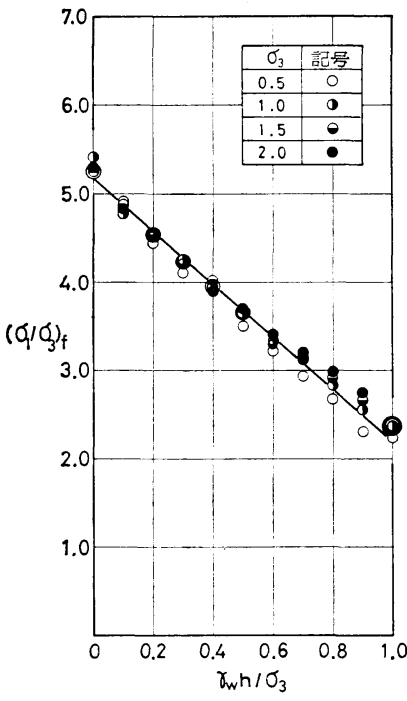

（a）透水型

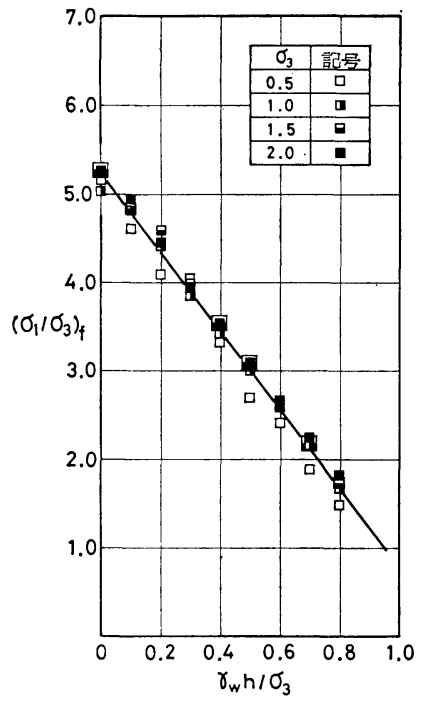

(b) 不透水型

図一9 豊浦砂の主応力比と $\gamma_{w} \boldsymbol{h} / \sigma_{3}$ の関係

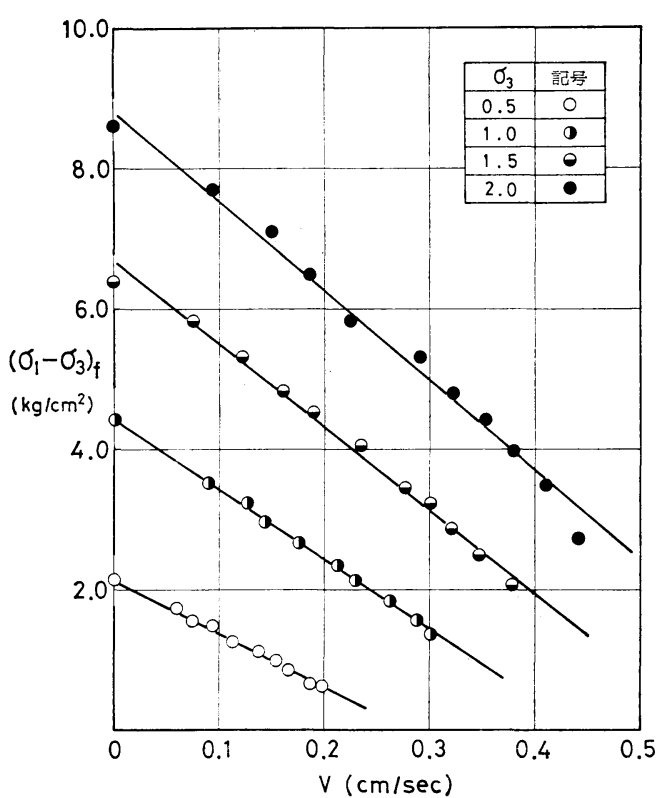

図一10 曹浦砂の破壊時の軸差応力と平均流速の関係

般の粒径分布の砂についても上記の関係がいえるであろ 5 .

\section{（5）強度定数}

強度定数は全応力法と有効応力法を用いて求め, その ときのせん断抵抗角をそれぞれ $\phi, \phi^{\prime}$ と表示する.

ところで, 有効応力に関してせん断抵抗角を求めるに は，すべり面上の間隚水圧の值が必要である．不透水型

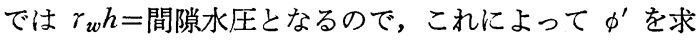
めた. この $\phi^{\prime}$ と全応力法による $\phi$ を $r_{w} h / \sigma_{3}$ との関係

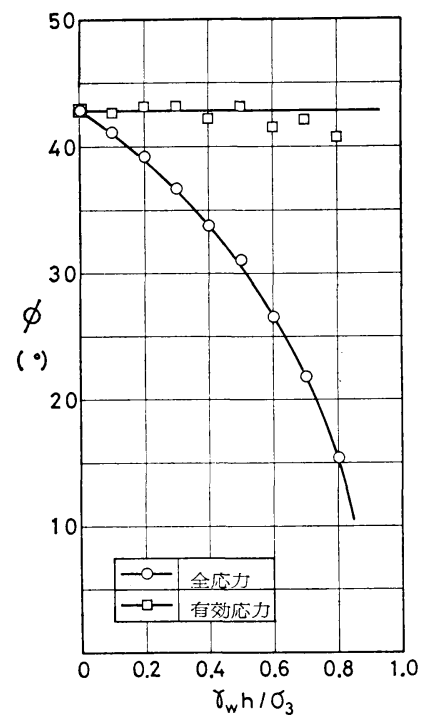

(a) 豊浦砂

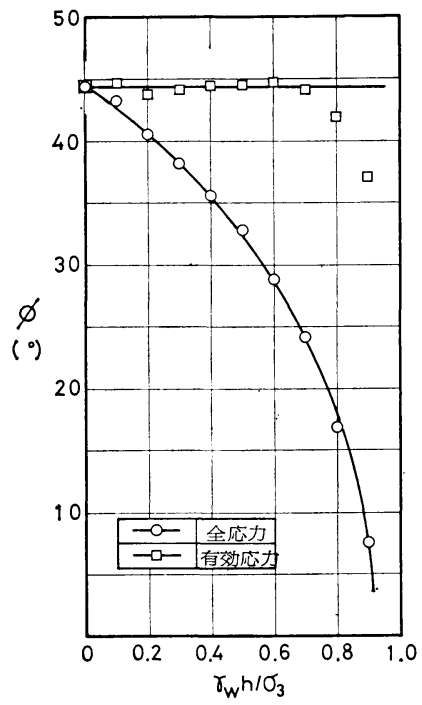

(b) 九大 砂

図一11 不透水型のせん断抵抗角と $\boldsymbol{r}_{w} \boldsymbol{h} / \boldsymbol{\sigma}_{3}$ の関係

で示したのが 図一11 (a)，(b) で，それぞれ豊浦砂と九 大砂についての結果である. $\phi$ は両者とも $r_{w} h / \sigma_{3}$ の増 加に従って急激に小さくなって強度が減少してゆく様子 がはっきりと現われている. 一方, $\phi^{\prime}$ は九大砂の $r_{w} h /$ $\sigma_{3}$ が 0.9 の值を除けばすべての值がほぼ $\phi_{d}$ の值に等 しくなっている. したがって, $\gamma_{w} h / \sigma_{3}$ の増加による $\phi$ の減少はすべて $r_{w} h$ つまり間隚水圧の増大によるもの であるといえる、結局，ここでは有効応力の概念によっ て強度の低下が十分に説明されたことになる.

さて, 透水型では間嚐水圧が 図一4のような台形分布 をなすので, ここでは供試体中央の值をすべり面上の平 


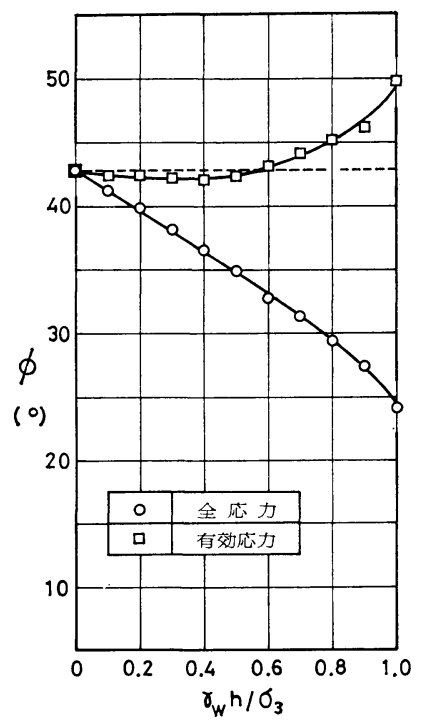

(a) 豊浦砂

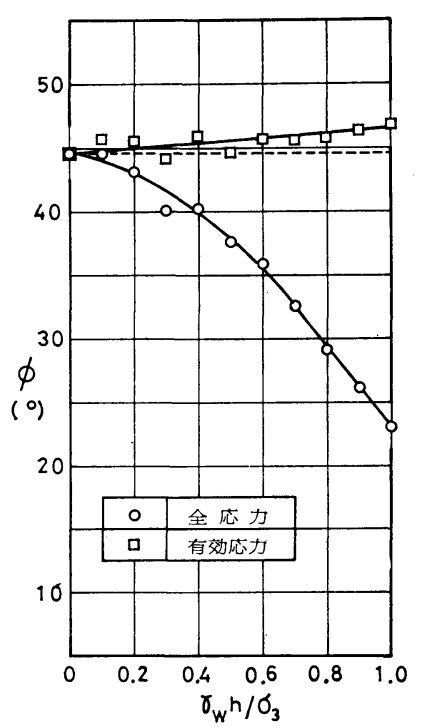

(b) 九大砂

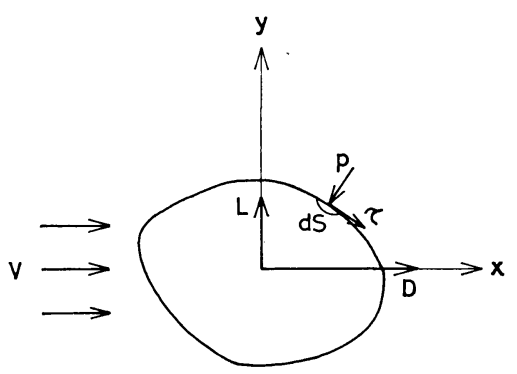

図一13 物体に作用する流体力

隚中を流れるときに失われるエネルギーで 摩擦損失となって表われるものである. 圧 力抵抗は土質力学で考えられる流速程度だ と, 摩擦抵抗に比べて非常に小さく通常は 無視されるものである.しかし, ボイリン グやパイピングを起こすような土中水の流 れでは, 圧力抵抗も何らかの形でそれらに 影響を及ぼしているのではないかというこ
均的な間隚水圧とみなして $\phi^{\prime}$ を求めている.

このようにして求めた透水型の $\phi, \phi^{\prime}$ を示したのが 図一12 (a)，(b) で，それぞれ豊浦砂と九大砂の結果を 示している. $\phi$ は不透水型と同様 $r_{w} h / \sigma_{3}$ の増加に従っ て急激に小さくなっている． $\phi$ に関するこのような傾向 は軸差応力と $r_{w} h / \sigma_{3}$ の関係からも一応予想されること であるが, この強度低下が不透水型と同様にすべて間隚 水圧の増大によるものであるのか，あるいは物体力とし ての浸透水圧の影響が何らかの形で入っているのかは興 味あるところである. 図を見ると豊浦砂では $\gamma_{w} h / \sigma_{3}$ が 0.7 あたりから $\phi^{\prime}$ は $\phi_{d}$ の値より大きくなり, 1.0 で は今回の実験での供試体の $\phi^{\prime}$ としては現実に存在し得 ない大きな值を示している. 一方，九大砂では $\phi^{\prime}$ は 0.7 あたりからわずかに $\phi_{d}$ の值からはずれてくるが, 值としては誤差の範囲内であるように思われる．豊浦砂 と九大砂でのこのような相違は透水係数の違いによるも のと考えられる.つまり 図一5で豊浦砂の流速は九大砂 飞比べて約 2 倍大きな值となって打り，その分だけ浸透 水圧の影響が大きく現われたのではないかと考えられ る.

ところで水理学では流れの中の静止物体に作用する流 体力は, 図一13 に示すように流れに垂直な揚力 $(L)$ と 流れの方向の抵抗力 $(D)$ に分けられる. 抵抗力は摩擦に よる表面抵抗 $\left(D_{f}\right)$ と圧力による形状抵抗 $\left(D_{p}\right)$ とに 分けられ，前者は摩擦抵抗ともよばれ物体表面の接線方 向に, 後者は圧力抵抗ともよばれ物体表面の垂直方向に 作用する力である. 以上 3 つの力のうち，土質力学の浸 透問題においては揚力は考える必要はなく，摩擦抵抗と 圧力抵抗のみを考えればよい，摩擦抵抗は流体が土の間
とが考えられる. そこでこの圧力抵抗を実際計算して みたが，本実験での流速の範囲内では無視し得るほど小 さいものであった．したがって豊浦砂の場合に $r_{w} h / \sigma_{3}$ が 0.7 以上で $\phi^{\prime}$ の值が $\phi_{d}$ の值より大きくなったこ とは, その差自体がわずかに数度のものであり実験的な ばらつきと考えるのが妥当である.

以上のことから, 三軸圧縮状態で砂供試体中を水が流 れている場合のせん断試験においても，間隚水圧を計測 することによって有効応力の概念の適用が十分に可能で あるといえる。

\section{4. まと め}

本論文は, 三軸圧縮状態にある砂供試体の底部から上 部一向けて浸透水を流し, そのときの砂のせん断強度が どのように変化するかを実験的に明らかにしたものであ る.

以下に本論文の結論を簡単に列記する.

（1）本実験に抢ける 砂供試体内の間隚水の流れは Darcy の法則に従い, 間隙水圧は供試体の底部から上部 一向かって直線的に変化し, 台形的な分布をする.

（2）本実験では破壊時の軸差応力は流速の増加に従 って側圧にはあまり関係なく, ほぼ同一の勾配で直線的 に減少する. したがって，小さな側圧に対してはわずか な流速の増加で破壊時の軸差応力が零に近づくことにな る.これはボイリング現象が拘束圧の小さい地表面付近 から内部に進行してゆくことを示唆している.

（3）浸透水圧の作用, つまり, $r_{w} h / \sigma_{3}$ の増大に従 って有効応力に関するせん断抵抗角 $\phi^{\prime}$ は排水試験によ 
るせん断抵抗角 $\phi_{d}$ より少し大きな値を示すようになる が，その差はわずかであり，本実験のような三軸圧縮状 態では浸透水圧と間淂水圧を同一のものとみなして有効 忘力の概念を適用することが十分に可能である.

しかし実験の性質上, 供試体内の間隙水圧は各所で異 ならざるを得ず, 厳密な意味での要素試験とはなりえな い. したがって, 実験から得られた種々の結果は供試体 全体の平均的な值を求めたことになっている.したがっ て, 今後はこの種の実験と平行して, 精度の高い模型実 験を行うことによって浸透水圧が土の強度にどのような 影響を及ぼしているかを明らかにしてゆきたい。

終わりに, 本研究は文部省科学研究費 (昭和 53 年度 奨励研究 (A)) の補助を得て行われたものである.ここ に記して謝意を表する。また，本研究を進めるにあたり 適切なご助言をいただいた宮崎大学工学部 藤本廣教 授, 同 横田漠助教授, 佐賀大学理工学部 鬼塚克忠助 教授, 九州大学工学部 平田登基男助手の諸氏に感謝の 意を表します. あわせて実験に協力いただいた九州大学 工学部土木工学科道路研究室の卒業生に感謝いたしま す.

\section{【記号】}
$A:=A^{\prime} \sigma_{3}$
$A^{\prime}: r_{w} h / \sigma_{3}=0$ のときの $\left(\sigma_{1} / \sigma_{3}\right)_{f}$ の值
$D:$ 流れの方向の抵抗力
$D_{f}:$ 表面抵抗（摩擦抵抗）
$D_{p}$ : 形状抵抗 (圧力抵抗)
$d S:$ 物体表面の微小面積
$D_{10}$ : 均等係数
$e_{0}$ : 初期間幥比
$G_{s}:$ 土粒子の比重

$i:$ 動水勾配

$k:$ 透水係数

$L:$ 流れに垂直な揚力

$p$ : 微小面積 $d S$ に作用する圧力

$\Delta V / V:$ 体積変化

$v:$ 間隚水の平均流速

$\alpha:$ 係数

$r_{w}:$ 水の単位体積重量

$r_{w} h$ : 浸透水供給タンクの水圧

$\varepsilon:$ 軸ひずみ

$\sigma_{1}, \sigma_{3}:$ 主応力

$\sigma_{1}{ }^{\prime}, \sigma_{3}{ }^{\prime}$ : 有効主応力

$\sigma_{1}-\sigma_{3}:$ 軸差応力

$\left(\sigma_{1}-\sigma_{3}\right)_{f}$ : 破壊時の軸差応力

$\left(\sigma_{1} / \sigma_{3}\right)_{f}:$ 破壊時の主応力比

$\tau:$ せん断応力

$\phi:$ 全応力に関する砂のせん断抵抗角

$\phi^{\prime}$ : 有効応力に関する砂のせん断抵抗角

$\phi_{d}:$ 排水試験による砂のせん断抵抗角

\section{参考文 献}

1）内田一郎・村田重之：浸透水圧を受ける砂の三軸圧縮試 験, 第 24 回土質工学シンポジウム論文集, pp. 131〜 136, 1979.

2）電力土木技術協会編: 最新フィルダム工学, 電力土木技 術協会, pp. $67 \sim 78,1972$.

3）土質工学会関西支部編: 二十周年記念誌，3. 掘削，士質 工学会関西支部, pp. 44 64, 1978.

4）たとえば，鈴木音彦：透水性地盤における鋼矢板の下を 回る浸透水流に関する模型実験, 土と基䃈, Vol. 13, No. 14, pp. $9 \sim 17,1965$.

5）たとえば，赤井浩一：浸透水流による盛土裏法面の 局部 破壞について, 土木学会論文報告集, 第 36 号, pp. 44 $\sim 49,1956$.

(1979.12.26 • 受付) 